\title{
Implementasi Metode Speed Up Robust Feature dan Scale Invariant Feature Transform untuk Identifikasi Telapak Kaki Individu
}

\author{
Muhammad Baresi Ariel ${ }^{1}$, Ratri Dwi Atmaja ${ }^{2}$, Azizah $^{3}$ \\ ${ }^{1,2,3}$ S1 Teknik Telekomunikasi, Fakultas Teknik Elektro, Universitas Telkom, Jl. Telekomunikasi, \\ Terusan Buah Batu, Bandung 40257
}

Penulis untuk Korespondensi/E-mail: baresi_ariel@hotmail.com

\begin{abstract}
Abstrak - Biometrik merupakan metode pengidentifikasian individu berdasarkan ciri fisiknya. Salah satu ciri fisik yang dapat digunakan untuk biometrik adalah telapak kaki. Ciri fisik ini dipilih karena memiliki tingkat keunikan yang tinggi, sehingga hampir tidak terdapat individu yang memiliki ciri yang sama. Metode-metode ekstraksi ciri seperti Scale Invariant Feature Transform (SIFT) dan Speed Up Robust Feature (SURF) akan sesuai jika digunakan untuk mendukung sistem identifikasi telapak kaki. Tahapan yang dilakukan untuk mendapatkan deskriptor dimulai dari scanning telapak kaki, pre-processing, ekstraksi ciri dengan menggunakan SURF dan SIFT sampai pada proses matching pada saat pengujian. Perbandingan keduanya dilihat dari aspek akurasi. Proses penentuan klasifikasi dan kelas menggunakan algoritma K-Nearest Neighbor (K- NN). Hasilnya akan menjadi datadata penelitian dalam paper ini. Diharapkan menggunakan metode SIFT dan SURF akan memberikan hasil dengan tingkat keakurasian yang tinggi.
\end{abstract}

Kata Kunci-Biometric, Footprint, SURF, SIFT, K-NN

Abstract - Biometric is a method used to identify indivduals using their physical features. One of the physical features that can be used for biometric is the footprint. The footprint was chosen because of having a high level of uniqueness where it is almost impossible to find two individuals that have the same footprint. Feature extraction methods such as Scale Invariant Feature Transform (SIFT) and Speed Up Robust Feature (SURF) are appropriate if used for footprint identification system. The steps used in obtaining descriptor start from scanning the footprint, pre-processing, feature extraction using SURF and SIFT and last the matching process. The comparison between the two methods will be observed by their accuracy. The K-Nearest Neighbor (K-NN) algorithm will be used for the classification process. The outputs will be used for research data in this research proposal. It will be expected that using SIFT and SURF for the feature extraction will result in high accuracy.

Keywords - Biometric, Footprint, SURF, SIFT, K-NN 


\section{PENDAHULUAN}

Cetiap manusia memiliki keunikan tersendiri Nyang digunakan untuk membedakan seseorang dengan orang lainnya. Ciri keunikan fisik yang dapat digunakan bermacam macam seperti sidik jari, telapak tangan, ris mata, bentuk wajah danlainnya. Keunikan fisik ini apabila diitengrasikan dengan penggunaan teknologi dapat digunakan sebagai sebuah sistem pengidentifikasi individu.Hal ini disebut dengan teknologi biometrik.

Salah satu fisik manusia yang unik yang dapat digunakan sebagai sistem identifikasi adalah menggunakan telapak kaki. Melalui penelitian yang sudah dilakukan [1] telah ditentukan ciri-ciri yang terdapat pada biometric telapak kaki. Sehingga dimungkinkannya penggunaan citra telapak kaki sebagai sistem yang mampu mengudentifkasi individu.

Speed Up Robust Feature (SURF) dan Scale Invariant Feature Transfrom (SIFT) adalah contoh metode yang digunakan untuk mendeteksi citra. Secara garis besar terdapat empat langkah penting dalam metode SURF yaitu interest point detector, scale space representation, feature description dan feature matching and recognition. Sedangkan terdapat juga empat langkah penting dalam metode SIFT yaitu mencari nilai ekstrim, menentukan keypoint, penentuan orientasi dan descriptor keypoint. Hasil ekstraksi yang diperoleh dari kedua metode tersebut akan diklasifikasi menggunakan $\mathrm{K}$ Nearest Neighbor.

Sejauh ini penilitian mengenai verifikasi identitas seseorang menggunakan telapak kaki telah banyak dilakukan dengan metode yang beragam. Pada penelitian oleh Khamael [2] dibahas pengenalan biometric telapak kaki dengan ekstraksi ciri menggunakan thresholding. Citra didapatkan dengan cara akuisisi inkfootprint dengan pengujiannya terhadap Mean Square Error (MSE). Lalu pada penelitian oleh Kumar dan Ramakrishnan [3] menggunakan ROI pada area tumit kaki. Metode yang digunakan adalah Modified Sequential Haar Energy (MSHET). Dengan pengujian menggunakan Sequential Haar Transform (SHT), Fourier Transform dan Discrete Cosine Transform (DCT) menghasilkan akurasi tertinggi masing-masing sebesar 92.375\%, 87.43\% dan
$83.64 \%$.

Berdasarkan hal tersebut maka dibuat penelitian yakni membuat sistem menggunakan matlab yang dapat mengidentifikasi biometrik pada individu dengan telapak kaki menggunakan pengolahan citra digital dengan metode Speed Up Robust Feature dan Scale Invariant Feature Transform. Pemilihan metode SURF dan SIFT untuk segmentasi dan pemilihan metode K-NN untuk klasifikasi.

\section{TINJAUAN PUSTAKA}

\section{Pengenalan Objek pada Komputer}

Pengenalan objek merupakan sebuah penelitian yang memadukan konsep citra digital, pengenalan pola, matematika dan statistik. Pengenalan objek memberikan klasifikasi terhadap objek. Dalam prosesnya, komputer akan mengambil komponen-komponen tertentu yang diperlukan untuk mengenali suatu objek pada citra yang ditangkapnya. Secara umum, pengenalan objek terdiri dari deteksi dan pengenalan. Komputer akan mencari dari mengidentifikasi komponen penting pada sebuah citra untuk mengetahui keberadaannya suatu objek yang kemudian akan diproses lebih lanjut, proses ini merupakan pengertian dari deteksi. Selain itu, pengenalan merupakan proses dimana objek yang telah dideteksi akan diambil ciri - cirinya dan diklasifikasikan sesuai dengan aplikasi dari sistem pengenalan objek. Terdapat pula beberapa tahapan penting pada sistem pengenalan objek yaitu preprocessing, ekstraksi fitur dan matching.

\section{Telapak Kaki}

Telapak kaki adalah bagian kulit terbawah, secara anatomis telapak kaki disebut sebagai sol. Telapak kaki juga memiliki kontur yang khas antar satu individu dengan yang lain. Bagian kulit pada telapak kaki memiliki garis halus menonjol yang keluar satu sama lain yang dipisahkan oleh alur yang membentuk struktur tertentu. Garis halus ini tidak berubah polanya sejak lahir kecuali perbuhan ukuran atau karena kondisi tertentu seperti terluka atau terbakar. 


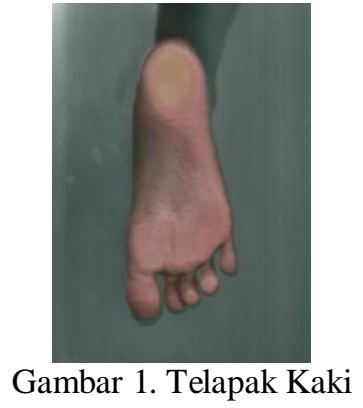

Kulit telapak kaki tidak ditumbuhi rambut dan tidak memiliki pigmen serta memiliki konsentransi pori keringat yang tinggi. Telapak kaki memiliki sejumlah lipatan yang terbentuk selama perkembangan embrio dalam Rahim. Telapak kaki mengandung lapisan kulit paling tebal karena selalu tertumpu bobot diatasnya. Selain itu, telapak kaki sangat sensitif terhadap sentuhan karena banyaknya ujung saraf yang berada dibawah permukannya.

\section{Biometrik}

Sistem biometrik adalah teknologi pengenalan diri dengan menggunakan bagian tubuh atau perilaku manusia. Sistem pengenalan diri adalah sistem untuk mengenali identitas seseorang secara otomatis dengan menggunakan teknologi komputer. Salah satu fungsi biometric adalah sebagai sistem keamanan yang dapat digunakan untuk mengidentifikasi pengguna. Terdapa banyak fitur yang sudah dikembangkan dalam biometrik seperti sidik jari, bentuk wajah, iris mata, bentuk telinga dan lain lain. Sistem akan mencocokkan hasil ciri yang telah dipindai dengan sebuah basis data acuan yang telah disiapkan sebelumnya.

\section{Citra Digital}

Suatu citra dapat didefinisikan sebagai fungsi $\mathrm{f}(\mathrm{x}, \mathrm{y})$ berukuran $\mathrm{M}$ baris dan $\mathrm{N}$ kolom, dengan $\mathrm{x}$ dan $\mathrm{y}$ adalah koordinat spasial dan amplituda $\mathrm{f}$ di titik koordinat $(\mathrm{x}, \mathrm{y})$ dinamakan intensitas keabuan dari citra pada titik tersebut. Apabila $x, y$ dan nilai amplituda $f$ secara keseluruhan berhingga dan bernilai diskrit maka dapat dikatakan bahwa citra tersebut adalah citra digital.

Citra digital dua dimensi yang berukuran $\mathrm{M}$ $x$ N dimana $f(0,0)$ berada pada sudut kiri atas dari matriks tersebut, sedangkan $\mathrm{f}(\mathrm{N}-1, \mathrm{M}-$ 1) berada pada sudut kanan bawah.



Gambar 2. Representasi Citra Digital

Citra digital merupakan suatu matriks dengan indeks baris dan kolomnya menyatakan posisi titik pada citra tersebut dan elemen matriks menyatakan tingkat keabuan pada titik tersebut.

\section{Speed Up Robust Feature}

Algoritma Speed Up Robust Feature (SURF) pertama kali dipublikasikan oleh peneliti dari ETH Zurich, Herbert Bay pada tahun 2006. Dalam pengembangannya Herbert Bay dibantu oleh dua rekannya yaitu Tinne Tuytelaars dan Luc Van Gool. SURF mampu mendeteksi fitur lokal suatu citra dengan handal dan cepat. Algoritma ini terinspirasi dari Scale Invariant Feature Transform (SIFT) terutama pada tahap scale space representation. Algoritma SURF menggunakan penggabungan algoritma integral image dan blob detection berdasarkan determinan dari matriks Hessian.

\section{1) Interest Point Detector}

Interest point detector digunakan untuk memilih titik yang mengandung banyak informasi dan sekaligus stabil terhadap gangguan lokal atau global dalam citra digital. Dalam algoritma SURF, dipilih interest point detector yang mempunyai sifat invariant terhadap skala, yaitu blob detection. Blob merupakan luas pada citra digital yang memiliki sifat konstan atau bervariasi dalam kisaran tertentu. Untuk melakukan komputasi blob detection digunakan determinan matriks Hessian dari citra. Jika diberikan titik $x=(x, y)$ pada citra I, matriks Hessian $H(x, \sigma)$ pada dengan skala ${ }^{\sigma}$ didefinisikan sebagai:

$H(x, \sigma)=\left[\begin{array}{ll}L_{x x}(x, \sigma) & L_{x y}(x, \sigma) \\ L_{x y}(x, \sigma) & L_{y y}(x, \sigma)\end{array}\right]$ 
Dimana $L_{x x}(x, \sigma)$ adalah konvolusi dari turunan kedua fungsi Gaussian $\frac{\partial^{2}}{\partial x^{2}} \mathrm{~g}(\sigma)$ dengan citra I pada titik. Definisi ini juga untuk $L_{x y}(x, \sigma)$ dan $L_{y y}(x, \sigma)$. Fungsi Gaussian didefinisikan sebagai:

$g(x)=\frac{1}{\sigma \sqrt{2 \pi}} e^{-\frac{x^{2}}{2 \sigma^{2}}}$

Dalam algoritma SURF, determinan matriks Hessian dihitung dari wavelet Haar dengan menggunakan integral image secara optimal (Crow, 1984). Determinan dari matriks Hessian digunakan sebagai dasar algoritma SURF karena sifat invariant terhadap skala, kestabilan dan mudah untuk diulang.

\section{2) Scale Space Representation}

Dengan ukuran citra yang berbeda - beda, akan sangat sulit untuk membandingkan fitur - fitur yang terdapat pada citra. Oleh karena itu, diperlukan suatu proses yang menangani perbedaan ukuran dengan menggunakan metode perbandingan skala. Dalam metode ini digunakan scale space dimana citra diimplementasikan dalam sebuah image pyramid (Lowe DG, 2004). Citra secara berulang mengalami proses smoothing dengan fungsi Gaussian secara beruntun dengan cara subsampling untuk mencapai tingkat tertinggi pada piramida. Dengan menggunakan integral image, perhitunganini tidak perlu dilakukan secara iterative dengan menggunakan filter yang sama, dapat dilakukan filter dengan ukuran sembarang ke dalam beberapa skala citra yang berbeda.

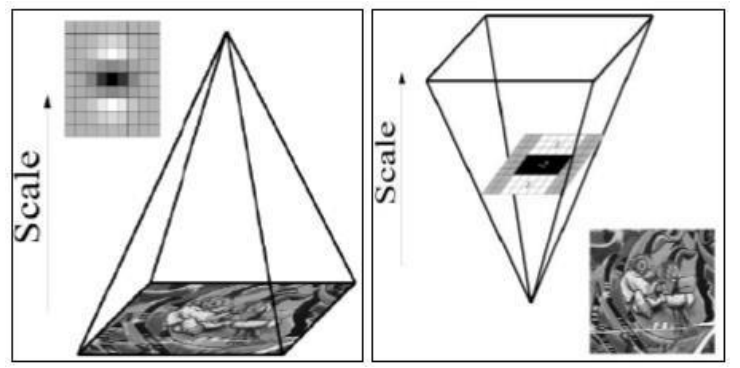

Gambar 3. Scale Space Representation

\section{3) Feature Description}

Fitur didefinisikan sebagai bagian yang mengandung banyak informasi terhadap suatu citra dan digunakan sebagai titik awal untuk algoritma deteksi objek. Tujuan dari feature description adalah untuk mendapatkan deskripsi dari fitur - fitur dalam citra yang diamati. Langkah pertama adalah melihat orientasi yang dominan pada titik perhatian yang terdapat dalam citra, kemudian membangun sebuah luas yang akan diambil nilainya dan mencari fitur korespondensi pada citra pembanding. Dalam penentuan orientasi suatu citra digunakan filter haar wavelet, disini dapat ditentukan tingkat kemiringan suatu fitur yang diamati. Selanjutnya untuk feature description dalam SURF digunakan hanya perhitungan gradient histogram dalam empat kelompok untuk mempercepat perhitungan, yaitu

$v=\left(\sum d_{x}, \Sigma d_{y}, \Sigma\left|d_{x}\right|, \Sigma\left|d_{y}\right|\right)$ dengan

$d_{x}$ adalah respon haar wavelet pada arah horizontal dan $d_{y}$ pada arah vertikal.

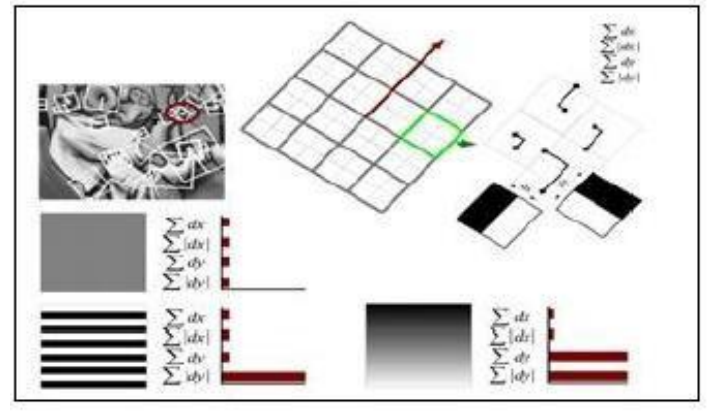

Gambar 4. Feature Description

4) Feature Matching and Recognition

Dalam tahap ini dibandingkan fitur hasil perhitungan sebelumnya hanya bila terdapat perbedaan kontras yang dideteksi melalui tanda dari trace matriks Hassian. Dengan cara ini, biaya komputasi dari algoritma SURF dapat dikatakan sangat minim.

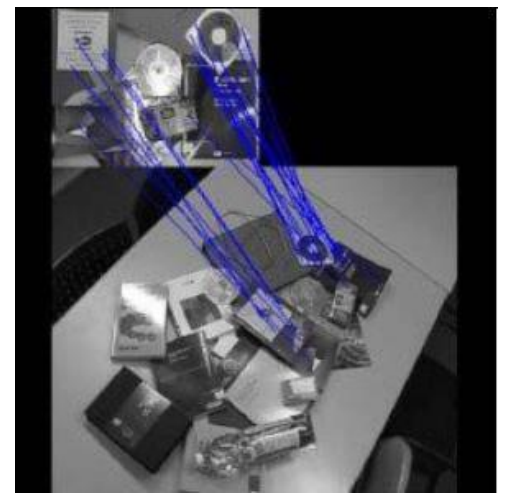

Gambar 5. Feature Matching

\section{Scale Invariant Feature Transform}

Pada tahun 1999, David G. Lowe seorang peneliti dari University of British Columbia memperkenalkan suatu metode baru dalam ekstraksi fitur dari suatu citra. Metode 
ekstraksi fitur ini disebut sebagai Scale Invariant Feature Transform (SIFT). Dengan menggunakan SIFT, citra akan diubah menjadi vector fitur lokal yang kemudian akan digunakan sebagai pendekatan dalam mendeteksi objek.

Sebagai metode ekstraksi fitur pada pengenalan objek. SIFT memiliki beberapa kelebihan sebagai berikut:

a. Hasil ekstraksi fitur bersifat invariant terhadap ukuran, translasi dan rotasi dua dimensi.

b. Hasil ekstraksi bersifat invariant sebagai terhadap perubahan iluminasi dan perubahan sudut pandang tiga dimensi.

c. Mampu mengekstrak banyak keypoint dari citra yang tipikal.

d. Hasil ekstraksi fitur benar mencirikan secara khusus.

Dengan kelebihan tersebut penggunaan metode SIFT banyak dikembangkan untuk aplikasi pengenalan objek. Secara garis besar, algoritma yang digunakan pada metode SIFT terdiri dari empat tahap yaitu:

a. Mencari nilai ekstrim pada skala ruang.

b. Mencari keypoint.

c. Penentuan orientasi.

d. Descriptor keypoint.

Setelah melalui tahapan tersebut maka akan diperoleh fitur lokal yang digunakan sebagai penciri dari suatu objek untuk diproses lebih lanjut.

1) Pencarian Nilai Ekstrim pada Skala Ruang Pencarian nilai ekstrim pada skala ruang merupakan tahap awal dalam penentuan keypoint dari sebuah citra. Dengan menggunakan fungsi Gaussian, citra pada skala ruang dapat didefenisikan sebagai fungsi $L(x, y, \sigma)$, yang diperoleh dari hasil konvolusi skala variabel Gaussian $G(x, y, \sigma)$, dengan citra masukan $I(x, y)$ sehingga diperoleh:

$L(x, y, \sigma)=G(x, y, \sigma) * I(x, y, \sigma)$

Citra hasil Difference-of-Gaussian $D\left(x_{s} y_{s} \sigma\right)$, diperoleh dengan melakukan operasi konvolusi pada citra masukan dengan filter Difference-ofGaussian (DoG).

$D(x, y, \sigma)=L(x, y, k \sigma)-L(x, y, \sigma)$
Dari persamaan diatas terlihat bahwa citra hasil $D o G$ sebenarnya merupakan selisih antara cita hasil pengaburan Gaussian dengan nilai skala $\mathrm{k}$ yang berbeda.

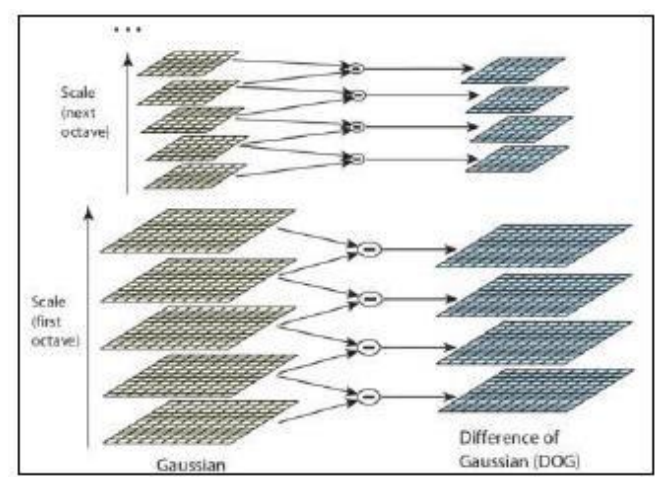

Gambar 6. Diagram Difference-of Gaussian

Citra hasil konvolusi kemdian dikelompokkan berdasarkan octave, nilai k ditetapkan di awal sehingga diperoleh jumlah citra kabur yang sama pada setiap octave serta diperoleh citra hasil DoG yang sama untuk setiap octave.

Setelah diperoleh citra DoG pada setiap octave, maka langkah selanjutnya adalah mencari kandidat keypoint. Kandidat keypoint dideteksi sebagai titik maksimum lokal atau titik minimum lokal dari citra hasil DoG. Untuk mencari nilai maksimum atau minimum lokal maka masing - masing piksel pada citra hasil DoG akan dibandingkan dengan delapan piksel disekitarnya yang berbeda pada skala yang sama dan dengan Sembilan piksel yang bersesuaian pada skala yang berbeda. Jika piksel tersebut merupakan maksimum atau minimum lokal, maka piksel tersebut akan dijadikan sebagai kandidat keypoint.

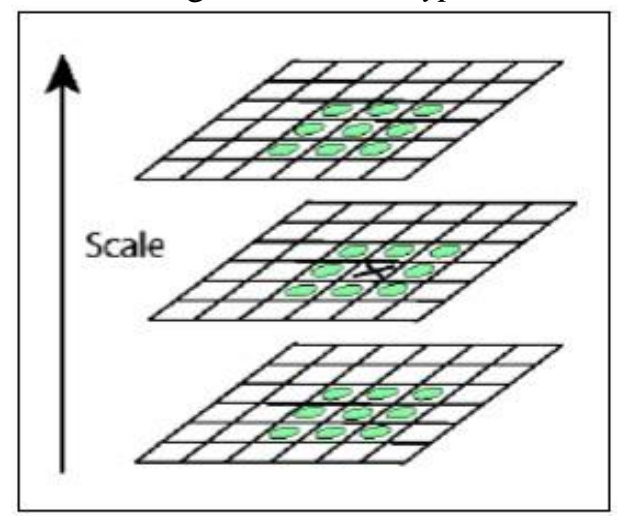

Gambar 7. Ilustrasi Pencarian Maksimum atau Minimum Lokal 
2) Mencari Keypoint

Setelah kandidat keypoint ditemukan maka langkah elanjutnya adalah untuk mengambil detail dari kandidat keypoint tersebut. Detail yang diambil merupakan lokasi, skala dan rasio kelengkungan inti dari kandidat keypoint. Pada tahap ini akan terjadi pengurangan jumlah kandidat keypoint. Dimana setiap keypoint yang dianggap sangat rentan terhadap noise akan dihilangkan, yaitu kandidat keypoint yang memiliki nilai kontras yang rendah dan kandidat keypoint yang kurang jelas dan terletak disepanjang tepi.

\section{3) Penentuan Orientasi}

Pada tahap ini, masing - masing keypoint yang diperoleh akan diberikan suatu orientasi yang tetap berdasarkan sifat - sifat lokal pada citra. Dengan adanya proses ini maka keypoint yang diperoleh dapat direpresentasikan relatif terhadap orientasi ini sehingga keypoint yang dihasilkan tidak terpengaruh terhadap adanya rotasi citra. Untuk menentukan orientasi dari masing - masing keypoint maka dilakukan perhitungan terhadap besarnya gradient dan sudut arah orientasi. Adapun perhitungan terhadap besar nilai gradient $m(x, y)$ dan arah orientasi $\theta(x, y)$ dilakukan menggunakan persamaan berikut:

$$
\begin{aligned}
& m(x, y)=\sqrt{(L(x+1, y)-L(x-1, y))^{2}+(L(x, y+1)-L(x, y-1))^{2}} \\
& \theta(x, y)=\tan ^{-1}((L(x, y)+1)-L(x, y-1)) /(L(x+1, y)-L(x-1, y)
\end{aligned}
$$

\section{4) Descriptor Keypoint}

Pada proses ini, masing - masing keypoint yang telah diorientasikan akan diberikan pencirian khusus. Proses ini bertujuan untuk mendapatkan keypoint yang invariant terhadap perubahan intesitas cahaya atau perubahan sudut pandang tiga dimensi.

Deskriptor akan diukur sebagai suatu histogram orientasi pada wilayah piksel dengan ukuran 4x4.Nilai orientasi diperoleh dari citra Gaussian yang memiliki skala terdekat dengan skala keypoint yang akan dihitung. Agar keypoint yang diperoleh invariant terhadap orientasi, maka koordinat dari descriptor dan gradient orientasi akan dirotasi relat terhadap orientasi dari keypoint. Kemudian fungsi pembebanan Gaussian, dengan besar nilai $\sigma$ satu setengah kali besar jendela descriptor, akan digunakan sebagai pembeban pada setiap besaran nilai dari titik sampel.

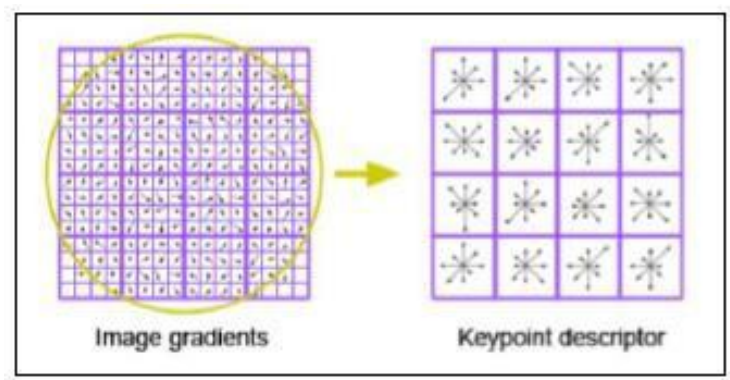

Gambar 8. Deskriptor Keypoint

Deskriptor keypoint pada gambar diatas menunjukkan adanya delapan arah pada masing-masing histogram orientasi dengan panjang masing- masing anak panah sesuai dengan besar nilai dari histogram asal. Selanjutnya descriptor keypoint yang telah diperoleh akan dinormalisasi untuk mengatasi pengaruh perubahan cahaya.

Setelah melalui tahapan tersebut, maka pada hasil akhir akan diperoleh suatu citra dengan keypoint berupa titik - titik berwarna kuning yang invariant terhadap sebagai macam perubahan.

Keypoint ini yang kemudian menjadi fitur fitur lokal pada suatu citra dan akan dicocokan dengan keypoint yang terdapat pada citra lain untuk menyesuaikan dengan objek yang tersedia pada dataset.

\section{K-Nearest Neighbor}

Algoritma K-Nearest Neighbor (K-NN) adalah metode yang digunakan untuk mengklasifikasikan suatu data. Pada data latih biasanya diambil lebih dari satu tetangga tetangga terdekat dengan data uji kemudian algoritma ini digunakan untuk menentukan kelasnya. Klasifikasi K-NN mempunyai dua langkah yaitu:

1. Menentukan tetangga terdekat, tergantung berapa banyaknya nilai $\mathrm{k}$ yang ditentukan (harus ganjil).

2. Menentukan kelas dari masing - masing tetangga tersebut. 


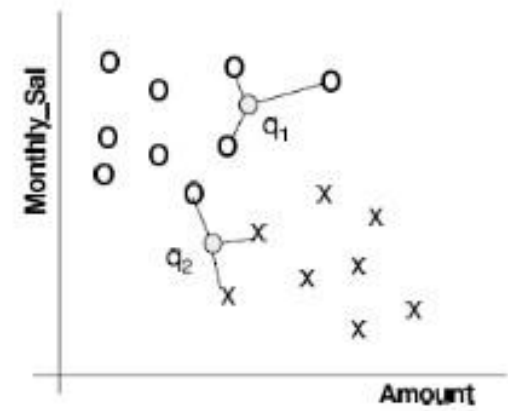

Gambar 9. Klasifikasi K-Nearest Neighbor

Pada gambar diatas, dimisalkan $\mathrm{K}=3$. Untuk node q2 akan mendapatkan tiga tetangga terdekatnya yaitu di $\mathrm{X}$ ada dua dan di $\mathrm{O}$ ada satu. Untuk node q1 akan mendapatkan tiga tetangga terdekatnya yaitu di $\mathrm{O}$ semuanya. Pada kasus q2, node tersebut akan melakukan voting, mana tetangga terbanyak untuk kemudian dipilih. Hasilnya adalah kelas $\mathrm{X}$ karena mayoritas tetangga terdekat dari q1. Untuk kasus q2 sistem algoritma akan langsung mengambil $\mathrm{O}$ adalah kelas terdekatnya karena semua tetangga dari q2 node $\mathrm{O}$.

Namun apabila nilai $\mathrm{K}$ yang diambil ada dua dengan perincian kelas terdekat masing masing kelas $\mathrm{X}$ dan kelas $\mathrm{O}$ satu buah maka menggunakan voting mayoritas sederhana tidak bisa dilakukan. Maka dari itu nilai $\mathrm{K}$ harus ganjil.

\section{METODE PENILITIAN}

Secara umum pemodelan sistem yang dirancang pada paper ini dapat digambarkan ke dalam diagram alir sebagai berikut:
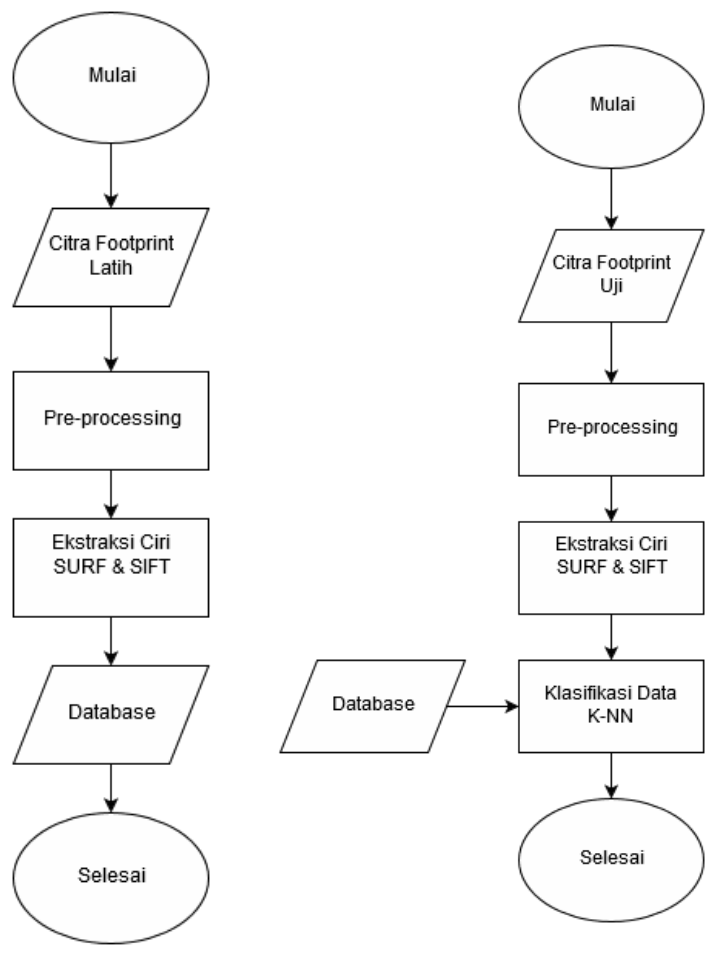

Gambar 10. Diagram Alir Tahap Pelatihan (a) dan Diagram Alir Tahap Uji (b)

Pada diagram alir tahap pelatihan, citra telapak kaki dari koresponden diambil dengan menggunakan alat pemindai. Kemudian citra - citra tersebut mengalami pre-processing untuk mendapatkan hasil citra inputan yang diinginkan. Citra greyscale keluaran dari preprocessing akan di ekstraksi cirinya menggunakan metode SURF dan SIFT untuk mendapatkan ciri - ciri yang unik yang digunakan untuk mengidentifikasi individu. Selanjutnya ciri - ciri tersebut disimpan dalam sebuah database yang nantinya akan digunakan sebagai pembanding pada tahap uji.

Pada diagram alir tahap uji, secara dasar proses yang dilalui pada tahap pelatihan dan tahap uji hampir sama, yang membedakan adalah hasil dari proses ekstraksi ciri akan dibandingkan dengan ciri citra latih yang sudah disimpan dalam database sebelumnya dengan pengklasifikasian mnggunakan metode K-NN. 


\section{HASIL DAN PEMBAHASAN}

Untuk mengetahui performansi dari sistem yang telah dirancang, maka diperlukan pengujian terhadap sistem yang telah dibuat dan dikembangkan. Pada proses pengujian sistem, dilakukan beberapa pengukuran tingkat keberhasilan dari sitem yang dirancang dengan melakukan analisis terhadap beberapa parameter.

\section{Pengujian dengan Ekstraksi Ciri SURF}

Hasil dari pengujian dengan ekstraksi ciri SURF adalah sebagai berikut:

Tabel 1. Pengujian Ekstraksi Ciri SURF pada Citra Telapak Kaki Kanan menggunakan Euclidean

\begin{tabular}{lccc}
\hline \multicolumn{4}{c}{ Distance } \\
K & $\begin{array}{c}\text { Jumlah } \\
\text { Data } \\
\text { Uji }\end{array}$ & $\begin{array}{c}\text { Jumlah } \\
\text { Data } \\
\text { Latih }\end{array}$ & $\begin{array}{c}\text { Persentase } \\
\text { Benar }\end{array}$ \\
\hline 1 & 140 & 100 & $42 \%$ \\
3 & 140 & 100 & $47 \%$ \\
5 & 140 & 100 & $44 \%$ \\
\hline \multicolumn{4}{l}{ Rata - Rata Persentase } \\
\hline
\end{tabular}

Tabel 2. Pengujian Ekstraksi Ciri SURF pada Citra Telapak Kaki Kanan menggunakan Cityblock Distance

\begin{tabular}{lccc}
\hline K & $\begin{array}{c}\text { Jumlah } \\
\text { Data } \\
\text { Uji }\end{array}$ & $\begin{array}{c}\text { Jumlah } \\
\text { Data } \\
\text { Latih }\end{array}$ & $\begin{array}{c}\text { Persentase } \\
\text { Benar }\end{array}$ \\
\hline 1 & 140 & 100 & $44 \%$ \\
3 & 140 & 100 & $47 \%$ \\
5 & 140 & 100 & $45 \%$ \\
\hline \multicolumn{4}{r}{ Rata - Rata Persentase } \\
\hline
\end{tabular}

Tabel 3. Pengujian Ekstraksi Ciri SURF pada citra Telapak Kaki Kanan menggunakan Consine Distance

\begin{tabular}{lccc}
\hline K & $\begin{array}{c}\text { Jumlah } \\
\text { Data } \\
\text { Uji }\end{array}$ & $\begin{array}{c}\text { Jumlah } \\
\text { Data } \\
\text { Latih }\end{array}$ & $\begin{array}{c}\text { Persentase } \\
\text { Benar }\end{array}$ \\
\hline 1 & 140 & 100 & $46 \%$ \\
3 & 140 & 100 & $46 \%$ \\
5 & 140 & 100 & $49 \%$ \\
\hline \multicolumn{4}{l}{ Rata - Rata Persentase } \\
\hline
\end{tabular}

Tabel 4. Pengujian Ekstraksi Ciri SURF pada Citra Telapak Kaki Kanan menggunakan Correlation Distance

\begin{tabular}{lccc}
\hline K & $\begin{array}{c}\text { Jumlah } \\
\text { Data } \\
\text { Uji }\end{array}$ & $\begin{array}{c}\text { Jumlah } \\
\text { Data } \\
\text { Latih }\end{array}$ & $\begin{array}{c}\text { Persentase } \\
\text { Benar }\end{array}$ \\
\hline 1 & 140 & 100 & $47 \%$ \\
3 & 140 & 100 & $47 \%$ \\
5 & 140 & 100 & $49 \%$ \\
\hline \multicolumn{4}{l}{ Rata - Rata Persentase } \\
\hline
\end{tabular}

Pada pengujian dengan ekstraksi ciri SURF semua hasil dapat dilihat pada tabel di atas. Rata - rata persentase tertinggi diperoleh ketika menggunakan perhitungan jarak Correlation Distance yaitu sebesar $47.6 \%$. Sedangkan rata - rata persentase terendah sebesar $44.3 \%$ dengan menggunakan perhitungan jarak Euclidean Distance. Perubahan nilai $\mathrm{k}$ juga mempengaruhi hasil persentase yang diperoleh. Sebagian besar dengan bertambahnya nilai $\mathrm{k}$ maka persentase besar akan bertambah pula.

\section{Pengujian dengan Ekstraksi Ciri SIFT}

Hasil dari pengujian dengan ekstraksi ciri SIFT adalah sebagai berikut:

Tabel 5. Pengujian Ekstraksi Ciri SIFT pada Citra

Telapak Kaki Kanan menggunakan Euclidean Distance

\begin{tabular}{lccc}
\hline K & $\begin{array}{c}\text { Jumlah } \\
\text { Data } \\
\text { Uji }\end{array}$ & $\begin{array}{c}\text { Jumlah } \\
\text { Data } \\
\text { Latih }\end{array}$ & $\begin{array}{c}\text { Persentase } \\
\text { Benar }\end{array}$ \\
\hline 1 & 140 & 100 & $51 \%$ \\
3 & 140 & 100 & $51 \%$ \\
5 & 140 & 100 & $51 \%$ \\
\hline \multicolumn{4}{l}{ Rata - Rata Persentase } \\
\hline
\end{tabular}

Tabel 6. Pengujian Ekstraksi Ciri SIFT pada Citra Telapak Kaki Kanan menggunakan Cityblock Distance

\begin{tabular}{lccc}
\hline K & $\begin{array}{c}\text { Jumlah } \\
\text { Data } \\
\text { Uji }\end{array}$ & $\begin{array}{c}\text { Jumlah } \\
\text { Data } \\
\text { Latih }\end{array}$ & $\begin{array}{c}\text { Persentase } \\
\text { Benar }\end{array}$ \\
\hline 1 & 140 & 100 & $50 \%$ \\
3 & 140 & 100 & $51 \%$ \\
5 & 140 & 100 & $54 \%$ \\
\hline \multicolumn{4}{l}{ Rata - Rata Persentase } \\
\hline
\end{tabular}


Tabel 7. Pengujian Ekstraksi Ciri SIFT pada Citra Telapak Kaki Kanan menggunakan Cosine Distance

\begin{tabular}{|c|c|c|c|}
\hline $\mathrm{K}$ & $\begin{array}{l}\text { Jumlah } \\
\text { Data } \\
\text { Uji }\end{array}$ & $\begin{array}{l}\text { Jumlah } \\
\text { Data } \\
\text { Latih }\end{array}$ & $\begin{array}{c}\text { Persentase } \\
\text { Benar }\end{array}$ \\
\hline 1 & 140 & 100 & $41 \%$ \\
\hline 3 & 140 & 100 & $41 \%$ \\
\hline 5 & 140 & 100 & $43 \%$ \\
\hline \multicolumn{3}{|c|}{ Rata - Rata Persentase } & $41.6 \%$ \\
\hline \multicolumn{4}{|c|}{$\begin{array}{c}\text { Tabel 8. Pengujian Ekstraksi Ciri SIFT pada Citr } \\
\text { Telapak Kaki Kanan menggunakan Correlation } \\
\text { Distance }\end{array}$} \\
\hline $\mathrm{K}$ & $\begin{array}{l}\text { Jumlah } \\
\text { Data } \\
\text { Uji }\end{array}$ & $\begin{array}{l}\text { Jumlah } \\
\text { Data } \\
\text { Latih }\end{array}$ & $\begin{array}{c}\text { Persentase } \\
\text { Benar }\end{array}$ \\
\hline 1 & 140 & 100 & $39 \%$ \\
\hline 3 & 140 & 100 & $37 \%$ \\
\hline 5 & 140 & 100 & $37 \%$ \\
\hline \multicolumn{3}{|c|}{ Rata - Rata Persentase } & $37.6 \%$ \\
\hline
\end{tabular}

Pada pengujian dengan ekstraksi ciri SIFT semua hasil dapat dilihat pada tabel di atas. Rata - rata persentase tertinggi diperoleh ketika menggunakan perhitungan jarak Cityblock Distance yaitu sebesar $51.6 \%$. Sedangkan rata - rata persentase terendah sebesar $37.6 \%$ dengan menggunakan perhitungan jarak Correlation Distance. Perubahan nilai $\mathrm{k}$ juga mempengaruhi hasil persentase yang diperoleh. Sebagian besar dengan bertambahnya nilai $\mathrm{k}$ maka persentase besar akan bertambah pula.

\section{KESIMPULAN}

Berdasarkan hasil penilitian maka dapat diambil kesimpulan bahwa nilai $\mathrm{K}$ mempengaruhi pada jumlah citra benar untuk sebagian besar perhitungan jarak. Semakin tinggi nilai k, maka jumlah citra akan bertambah. Dengan melihat hasil pengujian yang telah diperoleh, maka ekstraksi ciri SURF lebih baik digunakan dibandingkan ekstraksi ciri SIFT dalam sistem pengidentifikasian individu menggunakan citra telapak kaki berdasarkan ketepatan dalam mengelompokkan citra.

\section{DAFTAR PUSTAKA}

[1] Uhl, Andreas dan Wild, Peter. (2008)."Wild footprint-Based Biometric Verication". Department of Computer Sciences University of Salzburg.

[2] Al-Dulaimi, Khamael Abbas. "Using Feature Extraction for Human Footprints Recignition". International Journal of Computer Applications (0975 - 8887) Vol. 64, no.3, 2013.

[3] V.D.A. Kumar dan M. Ramakrishnan. "Footprint Recognition using Modified Sequential Haar Energy Transform (MSHET)". IJCSI International Journal of Computer Science Issues, vol.7, Issue 3, no. 5, 2010.

[4] Arief, Rommy Rakhman. (2010). Tugas Akhir Analisis Penggunaan Scale Invariant Feature Transform Sebagai Metode Ekstraksi Fitur Pada Pengenalan Jenis Kendaraan. Jakarta: Universitas Indonesia.

[5] Wibowo, Daniel S. Anatomi Tubuh Manusia.Jakarta. Gramedia. 2005

[6] Putra, Darma : "Sistem Biometrika". Andi. 2009

[7] Muntasa A. dan Purnomo. Konsep Pengolahan Citra Digital dan Ekstraksi Fitur. Yogyakarta : Graha Ilmu. 2010

[8] Lowe, D.G. (1999). "Object Recognition from Local Scale Invariant Keypoints". Vancouver: Computer Science Department University of British Columbia

[9] Padragi, Cunningham dan Sarah Jane Delany, "k- Nearest Neighbor Classifier", Technical Report UCDCSI, vol. 4, pp 1-2, 2007 